\title{
Protein Carbonylation
}

\author{
Yuichiro J. Suzuki, Marina Carini, ${ }^{2}$ and D. Allan Butterfield ${ }^{3}$
}

$\mathbf{P}$ ROTEIN CARBONYLATION is a type of protein oxidation that can be promoted by reactive oxygen species. It usually refers to a process that forms reactive ketones or aldehydes that can be reacted by 2,4-dinitrophenylhydrazine (DNPH) to form hydrazones. Direct oxidation of side chains of lysine, arginine, proline, and threonine residues, among other amino acids, in the "primary protein carbonylation" reaction produces DNPH detectable protein products $(11,15,23)$. DNPH derivatizable protein products can also be formed in the "secondary protein carbonylation" reaction via the addition of aldehydes such as those generated from lipid peroxidation processes $(14,21)$. Oxidative decomposition of polyunsaturated fatty acids initiates chain reactions that lead to the formation of a variety of carbonyl species (three to nine carbons in length), the most reactive and cytotoxic being $\alpha, \beta$-unsaturated aldehydes (4-hydroxy-trans-2-nonenal and acrolein), di-aldehydes (malondialdehyde and glyoxal), and keto-aldehydes (4-oxo-trans-2-nonenal). Although the biology of oxidative protein modifications is complex and remains incompletely defined, protein carbonylation and chemistry of the reactions that give rise to carbonyl groups have been well characterized (24).

The development of the antibody against DNPHderivatized proteins revolutionalized the studies of carbonylated proteins by allowing for the use of immunological techniques $(16,17,22)$. More recently, these methods contributed to a rapid progress in proteomic analyses of carbonylated proteins using two-dimensional gel electrophoresis, followed by immunoblotting and mass spectrometry. This redox proteomics approach allowed for the identification of carbonylated proteins in various diseases in humans, animals models, and cell models, and has provided important information to biologists by describing the effects of modifications by carbonyl species on protein function, as well as the consequences of such modifications at the cellular level.

Butterfield and co-workers developed this proteomics approach to identify specifically oxidized proteins in Alzheimer's disease by detecting carbonylated proteins $(7,10,12)$. In this issue, Sultana et al. (25) used a redox proteomics approach to identify specifically carbonylated proteins in the inferior parietal lobule from human subjects with mild cognitive impairment and early stage Alzheimer's disease, providing insights to the mechanism of the progression of this disease.
Hussain, Barreiro and co-workers have championed the understanding of carbonylated proteins in skeletal muscle dysfunctions during various disease processes such as chronic obstructive pulmonary disease and sepsis $(5,6)$. In this issue, Barreiro and Hussain (4) review their studies on carbonylated proteins in skeletal muscle dysfunction. Further, Barreiro and co-workers report their data on carbonylated proteins in skeletal and cardiac muscle of cachectic rats (18).

Burcham and co-workers have previously shown that cell exposure to acrolein results in the reaction with cysteine groups, forming protein carbonyls (8). In this issue, Burcham et al. (9) demonstrate that intermediate filament proteins are targets of acrolein-induced protein carbonylation in A549 lung epithelial cells, providing evidence for the involvement of carbonylation of these proteins during smoke-induced lung injury.

In addition to the identification of proteins that are carbonylated in various disease models, advancement in mass spectrometry technology has allowed for sophisticated mechanistic studies of carbonylated proteins in oxidative stress conditions. In this issue, Dalle-Donne and co-workers report the identification of amino acids within the human serum albumin molecule that are carbonylated in response to cigarette smoke extract exposure (13).

In addition to the well-established roles of protein carbonylation in oxidative stress, this oxidation process may also play roles in cell signal transduction as described by Suzuki and co-workers $(26,27)$. This suggests that cellular regulatory mechanisms of protein carbonylation may be complex, which might include means to promote and eliminate protein carbonyls. While enzymatic reversal of the proteincarbonyl modifications has not yet been detected, an enzymatic reversal mechanism for protein-methionine sulfoxide modifications exits and may play a role in the regulation of protein carbonylation, as described by Moskovitz and co-workers (19).

These pathophysiologic roles of protein carbonylation in oxidation stress and oxidant signaling suggest that compounds, which regulate carbonyl content, may have clinical value. An alternative strategy to the antioxidant intervention based on compounds acting as free radical scavengers is to detoxify oxidative-derived carbonyl reaction products. Trapping of lipid-derived reactive carbonyl species (identified as

\footnotetext{
${ }^{1}$ Department of Pharmacology, Georgetown University Medical Center, Washington, District of Columbia.

${ }^{2}$ Dipartimento di Scienze Farmaceutiche "Pietro Pratesi", Università degli Studi di Milano, Milan, Italy.

${ }^{3}$ Department of Chemistry, Center of Membrane Sciences, and Sanders-Brown Center on Aging, University of Kentucky, Lexington, Kentucky.
} 
the chemical intermediates between hyperglycemia, hyperlipidemia, and their complications) seems to be very promising, and represents a new therapeutic target on which the efforts of the medicinal chemists should focus in the near future. Promising results have been obtained in preclinical studies, where compounds belonging to different chemical classes, but sharing a carbonyl quenching mechanism, were found to be effective in the prevention/treatment of carbonylassociated diseases such as diabetes and metabolic distress syndrome $(2,3)$. Hence, the generation of drugs sharing both antioxidant and carbonyl scavenging properties represents a new therapeutic challenge in the treatment of carbonyl stress-associated diseases (20). In this regard, Carini and co-workers report in this issue that edaravone is not only a reactive oxygen species scavenger, but also a reactive carbonyl scavenger (1).

Protein carbonylation is a well-used marker for oxidative stress. Recent progress in redox proteomics and mass spectrometry identified carbonylated proteins during various disease states. Protein carbonylation may also mediate redox signaling processes, which may result in pathogenesis. Thus, the development of agents, which can control cellular protein carbonylation status, should contribute to the development of therapeutic strategies against various diseases.

\section{Acknowledgments}

This work was supported in part by National Institutes of Health (NIH) grant R01 HL72844 [YJS], Ministero Istruzione, Università e Ricerca (MIUR) grant PRIN 2007 20079SLZMC_003 [MC], and NIH grant AG-05119 [DAB].

\section{References}

1. Aldini G, Vistoli G, Regazzoni L, Benfatto MC, Bettinelli I, and Carini M. Edaravone inhibits protein carbonylation by a direct carbonyl scavenging mechanism: Focus on reactivity, selectivity, and reaction mechanisms. Antioxid Redox Signal 12: 381-392, 2010.

2. Aldini G, Dalle-Donne I, Colombo R, Maffei Facino R, Milzani A, and Carini $\mathrm{M}$. Lipoxidation-derived reactive carbonyl species as potential drug targets in preventing protein carbonylation and related cellular dysfunction. Chem Med Chem 1: 1045-1058, 2006.

3. Aldini G, Dalle-Donne I, Facino RM, Milzani A, and Carini $M$. Intervention strategies to inhibit protein carbonylation by lipoxidation-derived reactive carbonyls. Med Res Rev 27: 817-868, 2007.

4. Barreiro E and Hussain SNA. Protein carbonylation in skeletal muscles: Impact on function. Antioxid Redox Signal 12: 417-429, 2010.

5. Barreiro E, Gea J, Corominas JM, and Hussain SN. Nitric oxide synthases and protein oxidation in the quadriceps femoris of patients with chronic obstructive pulmonary disease. Am J Respir Cell Mol Biol 29: 771-778, 2003.

6. Barreiro E, Gea J, Di Falco M, Kriazhev L, James S, and Hussain SN. Protein carbonyl formation in the diaphragm. Am J Respir Cell Mol Biol 32: 9-17, 2005.

7. Boyd-Kimball D, Sultana R, Poon HF, Lynn BC, Casamenti F, Pepeu G, Klein JB, and Butterfield DA. Proteomic identi- fication of proteins specifically oxidized by intracerebral injection of amyloid beta-peptide (1-42) into rat brain: implications for Alzheimer's disease. Neuroscience 132: 313-324, 2005.

8. Burcham PC and Fontaine F. Extensive protein carbonylation precedes acrolein-mediated cell death in mouse hepatocytes. J Biochem Mol Toxicol 15: 309-316, 2001.

9. Burcham PC, Raso A, and Thompson CA. Intermediate filament carbonylation during acute acrolein toxicity in A549 lung cells: Functional consequences, chaperone redistribution, and protection by bisulfite. Antioxid Redox Signal 12: 337-347, 2010.

10. Butterfield DA, Perluigi M, and Sultana R. Oxidative stress in Alzheimer's disease brain: New insights from redox proteomics. Eur J Pharmacol 545: 39-50, 2006.

11. Butterfield DA, and Stadtman ER. Protein oxidation processes in aging brain. In: Advances in Cell Aging and Gerontology Volume 2, edited by Timiras PS and Bittar EE. Greenwich, CT: JAI Press, 1997, pp. 161-191.

12. Castegna A, Aksenov M, Aksenova M, Thongboonkerd V, Klein JB, Pierce WM, Booze R, Markesbery WR, and Butterfield DA. Proteomic identification of oxidatively modified proteins in Alzheimer's disease brain. Part I: Creatine kinase $\mathrm{BB}$, glutamine synthase, and ubiquitin carboxy-terminal hydrolase L-1. Free Radic Biol Med 33: 562-571, 2002.

13. Colombo G, Aldini G, Orioli M, Giustarini D, Gornati R, Rossi R, Colombo R, Carini M, Milzani A, and DalleDonne I. Water-soluble $\alpha, \beta$-unsaturated aldehydes of cigarette smoke induce carbonylation of human serum albumin. Antioxid Redox Signal 12: 349-364, 2010.

14. Grimsrud PA, Xie H, Griffin TJ, and Bernlohr DA. Oxidative stress and covalent modification of protein with bioactive aldehydes. J Biol Chem 283: 21837-21841, 2008.

15. Levine RL. Carbonyl modified proteins in cellular regulation, aging, and disease. Free Radic Biol Med 32: 790-796, 2002.

16. Levine RL, Williams JA, Stadtman ER, and Shacter E. Carbonyl assays for determination of oxidatively modified proteins. Methods Enzymol 233: 346-357, 1994.

17. Levine RL, Wehr N, Williams JA, Stadtman ER, and Shacter E. Determination of carbonyl groups in oxidized proteins. Methods Mol Biol 99: 15-24, 2000.

18. Marin-Corral J, Fontes CC, Pascual-Guardia S, Sanchez F, Olivan M, Argilés JM, Busquets S, López-Soriano FJ, and Barreiro E. Redox balance and carbonylated proteins in limb and heart muscles of cachectic rats. Antioxid Redox Signal 12: 365-380, 2010.

19. Moskovitz J and Oien DB. Protein carbonyl and the methionine sulfoxide reductase system. Antioxid Redox Signal 12: 405-415, 2010.

20. Negre-Salvayre A, Coatrieux C, Ingueneau C, Salvayre R. Advanced lipid peroxidation end products in oxidative damage to proteins. Potential role in diseases and therapeutic prospects for the inhibitors. Br J Pharmacol 153: 6-20, 2008.

21. Sayre LM, Lin D, Yuan $Q$, Zhu X, and Tang X. Protein adducts generated from products of lipid oxidation: focus on HNE and one. Drug Metab Rev 38: 651-675, 2006.

22. Shacter E, Williams JA, Lim M, and Levine RL. Differential susceptibility of plasma proteins to oxidative modification: examination by western blot immunoassay. Free Radic Biol Med 17: 429-437, 1994. 
23. Stadtman ER and Levine RL. Protein oxidation. Ann NY Acad Sci 899: 191-208, 2000.

24. Stadtman ER and Levine RL. Chemical modification of proteins by reactive oxygen species. In: Redox Proteomics: From Protein Modifications to Cellular Dysfunction and Diseases, edited by Dalle-Donne I, Scaloni A, and Butterfield DA. Hoboken NJ: John Wiley \& Sons, 2006, pp. 3-23.

25. Sultana R, Perluigi M, Newman SF, Pierce WM, Cini C, Coccia R, and Butterfield DA. Redox proteomic analysis of carbonylated brain proteins in mild cognitive impairment and early Alzheimer's disease. Antioxid Redox Signal 12: 325336, 2010.

26. Wong CM, Cheema AK, Zhang L, and Suzuki YJ. Protein carbonylation as a novel mechanism in redox signaling. Circ Res 102: 310-318, 2008.

27. Wong CM, Marcocci L, Liu L, and Suzuki YJ. Cell signaling by protein carbonylation and decarbonylation. Antioxid Redox Signal 12: 393-404, 2010.
Address correspondence to: Dr. Yuichiro J. Suzuki

Department of Pharmacology Georgetown University Medical Center Room NW403, Medical-Dental Building 3900 Reservoir Road NW Washington, DC 20057

E-mail: ys82@georgetown.edu

Date of first submission to ARS Central, September 9, 2009; date of acceptance, September 10, 2009.

Abbreviation Used

$\mathrm{DNPH}=$ 2,4-dinitrophenylhydrazine 
